\title{
A controlled study of diet in patients with gout
}

\author{
T. GIBSON, A. V. RODGERS, H. A. SIMMONDS, F. COURT-BROWN, \\ E. TODD, ANDV. MEILTON
}

From the Departments of Rheumatology, Medicine, and Dietetics, Guy's Hospital, London SE1 9RT

SUMmaRY To determine whether patients with gout have a diet which is distinctive in quality or quantity a careful dietary questionnaire was posed over 7 days to 61 men with gout and 52 control subjects. The average daily intake of most nutrients, including total purine nitrogen, was similar except that the patients with gout drank significantly more alcohol. Beer was the most popular beverage, and $25(41 \%)$ of those with gout consumed more than $60 \mathrm{~g}$ alcohol daily (equivalent to 2.5 litres of beer). The heavy drinkers had a significantly higher intake of purine nitrogen, half of which was derived from beer. Though the effect of ingested purine on the blood uric acid is difficult to estimate, it probably was sufficient to have a clinical effect, augmenting the hyperuricaemic effect of alcohol itself.

Many studies have demonstrated an association between body weight, obesity, and blood uric acid levels. ${ }^{12}$ In general, patients with a history of gout are heavier and more obese than healthy controls. ${ }^{34}$ These observations provide circumstantial evidence that dietary overindulgence contributes to the development of hyperuricaemia in susceptible individuals. A relationship between excessive alcohol intake and hyperuricaemia is well established, ${ }^{56}$ and there is historical and more recent evidence that gouty subjects enjoy good food. ${ }^{78}$ However, it has not been shown that food consumption is excessive among those with gout, nor has there been any serious attempt to determine whether their diets are qualitatively distinctive. The present study attempts to compare the diet of a group of gouty patients with that of age-matched persons not suffering from gout.

\section{Material and methods}

A dietary questionnaire was given to 61 men with a history of gout and to 52 male patients with backache, neck pain, or soft-tissue rheumatism. None of the latter gave histories of gout. All subjects were outpatients attending the Department of Rheumatology, Guy's Hospital. Some of those with gout were receiving hypouricaemic treatment at the time of the study, but none had received dietary counselling.

All subjects were weighed and their heights measured. A nonfasting morning blood sample was

Accepted for publication 15 February 1982.

Correspondence to Dr T. Gibson, Department of Rheumatology. obtained for estimation of plasma uric acid, which was measured by the uricase method adapted to the AutoAnalyzer. Social class was determined on the basis of occupation. ${ }^{9}$

The questionnaires were explained orally and supplemented with written instructions. Participants were required to indicate with a tick and roughly quantify those foods and beverages consumed at each mealtime for 7 days. A comprehensive list of foods, variously prepared, was outlined in the questionnaire for each conventional meal. The completed questionnaires were then checked and verified by interview with a dietician. The details were coded and food constituents calculated by computer with the use of standard tables of food analysis. ${ }^{10}$ Purine intakes were calculated by hand from 2 different reference sources. ${ }^{11}{ }^{12}$ The average quantity of nutrients consumed daily was estimated for each subject, and the values of control and gout patients were compared.

Dietary information was compiled over a prolonged period, and the influence of seasonal variation on the results was assessed by repeating the questionnaires in 11 gout patients after a 6 -month interval. The assessments of nutritional intake were compared statistically by the 2-tailed Mann-Whitney $U$ test and the clinical data by Student's $t$ test.

\section{Results}

Details of the gouty and control subjects are shown in Table 1 . The ages of the 2 groups were similar. The 


\section{Gibson, Rodgers, Simmonds, Court-Brown, Todd, Meilton}

mean body weight of the gouty was significantly greater than that of the controls, and their obesity, as measured by the ponderal index, was more pronounced but not significantly. There were slightly more gouty patients in social classes 1 and 2 and proportionally fewer in class 4 , but the distribution of social classes was otherwise even.

The period required to accumulate the data raised the possibility that there might be fluctuations of diet according to the time of year when individuals responded to the questionnaire. Dietary intake of 11 gouty patients during autumn and winter differed from that in the spring and summer (Table 2). In

Table 1 Clinical details of gout and control subjects and distribution of social classes: mean $\pm S D$

\begin{tabular}{lcc}
\hline & \multicolumn{1}{l}{ Gout } & \multicolumn{1}{l}{ Controls } \\
\hline Number & 61 & \multicolumn{2}{c}{52} \\
Mean age & $52 \pm 12$ & $49 \pm 12$ \\
Body wt. (kg) & $83 \pm 15$ & $77 \pm 10^{*}$ \\
Ponderal index & $12 \cdot 18 \pm 0 \cdot 6$ & $12 \cdot 24 \pm 0 \cdot 7$ \\
Plasma uric acid (mmol/l) & $0.49 \pm 0.07$ & $0 \cdot 39 \pm 0.08^{* *}$ \\
Social class & & \\
1 & $9(15 \%)$ & $4(8 \%)$ \\
2 & $8(13 \%)$ & $4(8 \%)$ \\
3 & $19(31 \%)$ & $15(29 \%)$ \\
4 & $13(21 \%)$ & $19(36 \%)$ \\
5 & $12(20 \%)$ & $10(19 \%)$ \\
\hline
\end{tabular}

${ }^{*} t=2 \cdot 26 ; \mathrm{p}<0.05 .{ }^{* *} t=6.9 ; \mathrm{p}<0.001$.

Table 2 Mean and range of daily average dietary intake of 11 gouty patients in autumn and winter compared with spring and summer. All figures are expressed as g/day except energy intake

\begin{tabular}{|c|c|c|}
\hline & $\begin{array}{l}\text { Autumn/winter } \\
\text { (Sept.-Feb.) }\end{array}$ & $\begin{array}{l}\text { Spring/summer } \\
\text { (March-Aug.) }\end{array}$ \\
\hline $\begin{array}{l}\text { Total purine nitrogen } \\
\text { Alcohol }\end{array}$ & $\begin{array}{l}0 \cdot 31(0 \cdot 17-0 \cdot 74) \\
68(12-191)\end{array}$ & $\begin{array}{l}0 \cdot 22(0 \cdot 09-0 \cdot 37) \\
60(2-143)\end{array}$ \\
\hline $\begin{array}{l}\text { Purine nitrogen from } \\
\text { alcoholic drinks } \\
\text { Energy (kJ) }\end{array}$ & $\begin{array}{l}0.08(0-0 \cdot 28) \\
11538 \\
(5997-13989)\end{array}$ & $\begin{array}{l}0.08(0-0 \cdot 12) \\
9910^{* *} \\
(4344-13145)\end{array}$ \\
\hline $\begin{array}{l}\text { Protein } \\
\text { Fat } \\
\text { Carbohydrate }\end{array}$ & $\begin{array}{r}99(39-143) \\
109(26-177) \\
221(86-335)\end{array}$ & $\begin{array}{l}79(36-125)^{* * *} \\
92(33-164) \\
198(89-332)^{*}\end{array}$ \\
\hline
\end{tabular}

${ }^{*} p<0.05 .{ }^{* *} p<0.01$.

Table 3 Times of year when dietary questionnaires were completed by 61 gout patients and 52 controls

\begin{tabular}{lllcl}
\hline & Dec.-Feb. & \multicolumn{4}{l}{ March-May June-Aug. } & Sept.-Nov. \\
\hline Gout & 19 & 15 & 12 & 15 \\
Control & 13 & 14 & 13 & 12 \\
\hline
\end{tabular}

particular, the average intake of carbohydrate, protein, and energy was significantly greater during the colder seasons. These differences are unlikely to have influenced the broad conclusions of the study, since questionnaires were posed to both groups over a similar time course (Table 3 ).

The average daily intakes of specific dietary constituents are shown in Table 4. Gouty patients consumed more energy, less protein, and less carbohydrate. None of these differences was statistically significant. The average purine nitrogen intake was identical in both groups. There was only one striking difference, and that was in alcohol consumption. Gouty patients drank significantly more than controls. Heavy drinkers were arbitrarily defined as those imbibing more than $60 \mathrm{~g}$ of alcohol a day (equivalent to $2 \cdot 5$ litres of beer), of whom there were 25 $(41 \%)$ among the gouty compared with $9(17 \%)$ of the controls $\left(\chi^{2}=7 \cdot 48 ; p<0 \cdot 01\right)$. Eighteen of the

Table 4 Average daily intake and range of food constituents (g/day) and energy (kilojoules) in 61 gouty and 52 control subjects

\begin{tabular}{lll}
\hline & Gout & Controls \\
\hline Total purine nitrogen & $0 \cdot 22(0 \cdot 07-0 \cdot 48)$ & $0 \cdot 22(0 \cdot 09-0 \cdot 7)$ \\
Alcohol & $54(0-191)$ & $31(0-128)^{*}$ \\
$\begin{array}{l}\text { Purine nitrogen from } \\
\text { alcoholic beverages }\end{array}$ & $0 \cdot 09(0-0 \cdot 28)$ & $0 \cdot 03(0-0 \cdot 18)$ \\
Energy (kJ) & 10231 & 9885 \\
& $(4550-16557)$ & $(4954-18554)$ \\
Protein & $87(47-135)$ & $99(49-264)$ \\
Fat & $97(44-168)$ & $99(52-188)$ \\
Carbohydrate & $220(75-364)$ & $233(109-427)$ \\
\hline
\end{tabular}

${ }^{*} \mathrm{p}<0.005$.

Table 5 Mean $( \pm S D)$ body size, plasma uric acid, and average (range) daily food intake of gouty patients drinking $60 \mathrm{~g}$ or morelday alcohol compared with patients drinking less than $60 \mathrm{~g} /$ day

\begin{tabular}{lcc}
\hline & $\begin{array}{l}\text { Alcohol } 60 \mathrm{~g} \text { or } \\
\text { morelday }\end{array}$ & Alcohol $<60$ g/day \\
\hline No. & $25(41 \%)$ & $36(59 \%)$ \\
Body wt. (kg) & $82 \pm 15 \cdot 6$ & $81 \pm 10 \cdot 9$ \\
$\begin{array}{l}\text { Ponderal index } \\
\text { Plasma uric acid }\end{array}$ & $12 \cdot 2 \pm 0 \cdot 68$ & $12 \cdot 2 \pm 0.64$ \\
$\quad$ (mmol/l) & $0 \cdot 51 \pm 0 \cdot 08$ & $0 \cdot 48 \pm 0 \cdot 06$ \\
Total purine nitrogen & $0 \cdot 28(0 \cdot 13-0 \cdot 48)$ & $0 \cdot 18(0 \cdot 07-0 \cdot 35)^{*}$ \\
Alcohol & $98(63-191)$ & $24(0-56)^{*}$ \\
Purine nitrogen from & & \\
$\quad$ alcoholic beverages & $0 \cdot 14(0 \cdot 03-0 \cdot 28)$ & $0.04(0-0.09)^{*}$ \\
Energy (kJ) & 10867 & 9571 \\
Protein & $(7812-16557)$ & $(4550-13497)$ \\
Fat & $87(57-130)$ & $87(47-135)$ \\
Carbohydrate & $91(44-152)$ & $104(46-168)$ \\
\hline *p<0.001. & $223(118-330)$ & $220(75-364)$ \\
\hline
\end{tabular}


gouty heavy drinkers consumed only beer, 8 mainly beer, and 3 favoured other alcoholic beverages. The preferences of the 9 heavy drinkers among the control patients were beer in 7, mainly beer in one, and other forms of alcohol in the remaining one patient.

The average dietary intake of the gouty heavy drinkers was compared with that of those gouty patients who drank less than $60 \mathrm{~g}$ of alcohol daily (Table 5). Although of similar body size, the heavy drinkers had a higher energy intake. The 2 subgroups had an otherwise similar dietary pattern except that the purine nitrogen intake of the heavy drinkers was significantly greater than that of the lesser drinkers and also the nongouty controls $(p<0 \cdot 001)$. The intake of purines from alcoholic beverages was significantly greater in the heavy drinkers, and half their average daily purine nitrogen was derived from this source.

\section{Discussion}

The relationship between body size and blood uric acid is well established. ${ }^{13-15}$ One aspect which cannot always be divorced from this close association is a direct effect of food on urate metabolism. However, the hypouricaemic effect of weight reduction in subjects on controlled diets implies that the relationship is one of cause and effect and not mediated through dietary factors. ${ }^{616}$ As in so many previous investigations, the gouty patients of the present study were heavier than their nongouty controls. Any demonstrable differences of diet could thus have partly influenced their hyperuricaemia by contributing to obesity. The energy intake of the gouty subjects was higher than that of the controls but not significantly.

Clearly body weight is not the sole arbiter of blood uric acid levels, and in one survey a high prevalence of hyperuricaemia and gout among business executives could not be attributed entirely to this effect. ${ }^{17}$ A similar study showed a predominance of patients from social classes 1 and 2 among those with gout and ascribed this to a diet with a high protein intake and to heavy beer consumption. ${ }^{18}$ In the 2 decades since these investigations were undertaken the dietary habits associated with affluence have followed a more egalitarian distribution, and the recently revived concept of 'aldermanic gout' does not have social connotations. ${ }^{19}$ Any atavistic influence of social class on the results reported here has been minimised by matching the 2 groups for this variable.

In the population survey quoted above ${ }^{18} \mathrm{a}$ diet rich in protein was invoked as a cause of hyperuricaemia. There is no evidence that ingested proteins can exert such an effect. Indeed there is good evidence to the contrary. Neglected studies by Raiziss $e t$ al..$^{20}$ and Lewis and Doisy ${ }^{21}$ showed that high protein diets are associated with increased urinary uric acid excretion. Subsequently it has been shown that a high protein intake will reduce blood uric acid and increase urate clearance, suggesting that protein is somehow capable of exerting a uricosuric effect. ${ }^{22}{ }^{23}$ Protein consumption was only marginally less in the gout patients of the present study.

Neither fat nor carbohydrate consumption differed significantly between the 2 groups of patients investigated. Experimental high fat diets capable of inducing ketosis may cause hyperuricaemia through impairment of renal urate excretion. ${ }^{24}{ }^{25}$ Reduced urinary uric acid has been observed following a high fat diet in the absence of ketosis, although this has not been confirmed. ${ }^{26}$ The amount of fat necessary to produce this response is considerable and is not likely to constitute part of a normal western diet. The only carbohydrate which has been shown to exert a direct effect on uric acid metabolism is fructose. Following intravenous fructose, uric acid production is rapidly enhanced, either due to an accentuated degradation of purine nucleotides ${ }^{27}$ or increased purine synthesis. ${ }^{28}$ Oral fructose may also increase blood uric acid levels, especially in those with a history of gout. ${ }^{29}$ Emmerson has suggested that if fructose is taken in sufficient quantity it may have clinical significance for those with boderline hyperuricaemia. ${ }^{\mathbf{3 0}}$

Animal and human experiments have illustrated that infusions of fructose cause a reduction of hepatic adenosine triphosphate (ATP), depletion of which has been invoked as a mechanism for increased uric acid production following intravenous fructose in man. ${ }^{31}$ It is of some interest that a decrease of liver ATP may also follow alcohol administration to the same animal model ${ }^{32}$ and in minipigs causes increased uric acid excretion. ${ }^{33}$ In man hepatic vein urate is greatly increased by intravenous infusions of both alcohol and fructose, suggesting that these dietary constituents share a similar mode of action on uric acid metabolism. ${ }^{34}$ These observations are in accord with the well known relationship between alcohol excess and gout. Unexplained hyperuricaemia has been recently advocated as a means of detecting concealed alcohol abuse.$^{35}$ These data are pertinent to the main finding of our study, which showed that, on average, gouty patients consumed considerably more alcohol than the control population. There is no doubt that ethanol itself may induce a rise of blood uric acid, and, when it is given in the quantities associated with wine consumption in France, ${ }^{36}$ the evidence suggests that uric acid synthesis is increased, as might be expected from the experiments previously cited. ${ }^{32}{ }^{34}$ However, the more conventional view is that alcohol exerts a hyperuricaemia effect through its conversion to lactic acid, which reduces uric acid excretion. ${ }^{37}$ In other studies of renal uric 
acid excretion after alcohol ingestion the observed reduction of urate clearance may have been mainly the effect of fasting rather than alcohol. ${ }^{38}{ }^{39}$

It can be reasonably assumed that, whatever the mechanism, the alcoholic content of many of the gouty patients' diets contributed in large measure to their hyperuricaemia. The consumption of beer as opposed to other alcoholic beverages is consistent with the traditional pattern of drinking in the United Kingdom. The not inconsiderable alcohol intake of the control group and the presence of a substantial number of heavy drinkers among them further attest to the magnitide of alcohol ingestion in Britain. ${ }^{40}$ Presumably an increased prevalence of gouty arthritis can be expected in response to the gradual rise in drinking since the nadir of the 1930s.

The proclivity for beer expressed by so many of the gouty patients in this study carried with it an added relevance. It has been suggested that beer may be especially harmful to those with gout because of its high purine content. ${ }^{41}$ The only available figures for alcoholic drinks indicate that their purine content is negligible except for beers. ${ }^{12}$ Our estimations indicated that, although the average purine nitrogen intake of gouty patients was not dissimilar from that of the control persons, the quantity derived from alcoholic drinks was greater in the gouty. When the purine nitrogen intake of the heavy drinking gouty patients was compared with that of the controls and that of the more abstemious gouty subjects, this difference achieved statistical significance. Half the dietary purine of the heavy drinkers was obtained from the beer they drank.

It is difficult to estimate to what extent blood uric acid is influenced by ingested purines, but Griebsch and Zollne $\mathrm{r}^{42}$ have suggested that this may be more than is often stated. Substitution of an entirely purine-free formula diet over a period of days has reduced blood uric acid of healthy men from an average of $0.3 \mathrm{mmol} / 1$ to $0.18 \mathrm{mmol} / 1 .^{42}$ The addition of dietary purines in such experiments has revealed a variable increase of blood uric acid depending on the formulation and dose of purines administered. For example, RNA has a greater effect than an equivalent amount of DNA ${ }^{43}$ ribomononucleotides greater than that of nucleic acids, ${ }^{42}$ and it is reported that adenine has a marked effect while guanine has none at all. ${ }^{44}$ Our own studies suggest that only $30-50 \%$ of ingested guanine may be absorbed. ${ }^{45}$

Very little is known about the precise identity and quantity of individual purines in most foods. Their different effects on urate metabolism make existing food tables of total purine nigrogen content inadequate for assessing the impact of specific foods, especially when cooked. For example, lentils and organ meats are considered to have very high levels of adenine and hypoxanthine, whereas anchovies and sardines, restrictions of which are often advocated in gout, contain very little. ${ }^{46}$ Thus, without knowing which of the purines were predominant in the diet of our gout patients, especially those who were heavy drinkers, we cannot state how much of their hyperuricaemia could be attributed to purine ingestion. Zollner has shown that when $0 \cdot 114 \mathrm{~g}$ of purine nitrogen is given as RNA the blood uric acid of healthy individuals on a purine-free diet will rise on average by $0.04 \mathrm{mmol} / 1 .^{47}$ The heavy drinkers in our study obtained $0 \cdot 14 \mathrm{~g}$ of purine nitrogen from beer, and, if it could be presumed that this was present as RNA, its influence on their blood uric acid levels would have been in excess of the value stated above. In gouty subjects absorption of dietary purines causes a steeper rise of blood uric acid than equivalent quantities in normouricaemic individuals. ${ }^{438}$ This almost certainly reflects the relative impairment of renal urate clearance shown by the majority of those with gout, ${ }^{49}$ a characteristic which we have demonstrated in the gout population of the present study. ${ }^{50}$

Comparison of diets in 11 gouty patients in different seasons revealed a greater intake of all constituents during the colder months, and the differences were greatest for energy, protein, and carbohydrate. Total purine nitrogen ingestion was also increased in autumn and winter, and the difference might have achieved statistical significance if a larger number had been examined in this way. However, there is no evidence to suggest that hyperuricaemia is more pronounced or gout more frequent at these times of year. No seasonal fluctuations of blood uric acid have been demonstrated in our own gouty patients.

In conclusion, we have shown that a group of hospital outpatients with gout ate a diet which was not dissimilar from that of a control group. We have confirmed the widely accepted notion that heavy alcohol consumption is characteristic of many with this illness. Those whose beer intake was greatest added substantially to their total purine intake and by this means probably augmented the hyperuricaemia effect of alcohol itself.

We are most grateful to the Arthritis and Rheumatism Council for financial support and to John Rowsen, Director of Computer Services, the John Elicott Centre.

\section{References}

1 Krizek V. Serum uric acid in relation to body weight. Ann Rheum Dis 1966; 25: 456-8.

2 Acheson R M, Chan Y K. New Haven survey of joint diseases. The prediction of serum uric acid in a general population. $J$ Chronic Dis 1969; 21: 543-3.

3 Grahame R, Scott J T. Clinical survey of 354 patients with gout. Ann Rheum Dis 1970; 29: 461-8. 
4 Gibson T, Grahame R. Gout and hyperlipidaemia. Ann Rheum Dis 1974; 33: 298-303.

5 Brochner-Mortensen K. 100 gouty patients. Acta Med Scand 1941; 106: 81-107.

6 Gibson T, Kilbourn K, Horner I, et al. Mechanisms and treatment of hypertriglyceridaemia in gout. Ann. Rheum Dis 1979; 38: 31-5.

7 Garrod A B. The Nature and Treatment of Gout and Rheumatic Gout. London: Walton and Maberly, 1859.

8 Kahn M F. Goutte obésité et plaisirs de la table. Comparaison entre 40 goutteux et 40 témoins. Nouv Presse Med 1976; 5: 1897-8.

9 Office of Population, Censuses and Surveys. Classification of Occupations. London: HMSO, 1970.

10 Paul A A, Southgate D A T. McCance and Widdowson's The Composition of Foods. London: HMSO, 1978.

11 McCance R A, Widdowson E M. The Composition of Foods. London: HMSO, 1960.

12 Johnson H J. Bridge's Dietetics for the Clinician. London: Kimpton, 1949.

13 Gertler M M, Garn S M, Levine S A. Serum uric acid in relation to age and physique in health and in coronary heart disease. Ann Intern Med 1951; 34: 1421-31.

14 Hollister L E, Overall J E, Snow H L. Relationship of obesity to serum triglyceride, cholesterol and uric acid and to plasma glucose levels. Am J Clin Nutr 1967; 20: 777-82.

15 Klein R, Klein B E, Comoni J C, et al. Serum uric acid. Its relationship to coronary heart disease, Evans County, Georgia. Arch Intern Med 1973; 132: 401-10.

16 Nicholls A, Scott J T. Effect of weight loss on plasma and urinary levels of uric acid. Lancet 1972; ii: 1223-4.

17 Dunn J P, Brooks G W, Mausner J, et al. Social class gradient of serum uric acid levels in males. JAMA 1963; 185: 431-6.

18 Popert A J, Hewitt J V. Gout and hyperuricaemia in rural and urban populations. Ann Rheum Dis 1962; 21: 154-63.

19 Rodnan G P. The pathogenesis of aldermanic gout: procatarctic role of fluctuations in serum urate concentration in gouty arthritis provoked by feast and alcohol. Arthritis Rheum 1980; 23: 737.

20 Raiziss G W, Dubin H, Ringer A I. Studies in endogenous uric acid metabolism.J Biol Chem 1914; 19: 473-85.

21 Lewis H B, Doisy E A. Studies in uric acid metabolism. 1. The influence of high protein diets on the endogenous uric acid elimination. J Biol Chem 1918; 36: 1-7.

22 Waslien C I, Calloway D H, Margen S. Uric acid production of men fed graded amounts of egg protein and yeast nucleic acid. Am J Clin Nutr 1968; 21: 892-7.

23 Matzkies F, Berg G, Madl $\mathrm{H}$. The uricosuric action of protein in man. Adv Exp Med Biol 1980; 122A: 227-31.

24 Scott J T, McCallum F M, Holloway V P. Starvation, ketosis and uric acid excretion. Clin Sci 1964; 27: 209-21.

25 Goldfinger S, Klinenberg J R, Seegmiller J E. Renal retention of uric acid induced by infusion of beta-hydroxylbutyrate and acetoacetate. $N$ Engl J Med 1965; 272: 351-5.

26 Adlersberg D, Ellenberg $M$. Effect of carbohydrate and fat in the diet on uric acid excretion.J Biol Chem 1939; 128: 379-85.

27 Fox I H, Kelley W N. Studies on the mechanism of fructoseinduced hyperuricaemia in man. Metabolism 1972; 21: 713-21.

28 Raivio K O, Becker M A, Meyer L J, et al. Stimulation of human purine synthesis de novo by fructose infusion. Metabolism 1975; 24: 861-9.
29 Stirpe F, Della Corte E, Bonetti E, et al. Fructose induced hyperuricaemia. Lancet 1970; ii: 1310-1.

30 Emmerson B T. Effect of oral fructose on urate production. Ann Rheum Dis 1974; 33: 276-80.

31 Bode J, Zelder O, Rumpelt H J, Wittkamp U. Depletion of liver adenosine phosphates and metabolic effects of intravenous infusion of fructose or sorbitol in man and in the rat. Eur J Clin Invest 1973; 3: 436-41.

32 Bernstein J, Videla L, Israel Y. Metabolic alterations produced in the liver by chronic ethanol administration. Changes related to energetic parameters of the cell. Biochem J 1973; 134: 515-21.

33 Taupitz-Stahn E. The effect of ethanol applications on uric acid metabolism in minipigs. Res Exp Med 1977; 170: 57-69.

34 Grunst J, Dietze J, Wicklmayr M. Effect of metabolic changes on uric production of human liver. In: Fleisch H, Robertson W G, Smith L H, Vahlinsiek W, eds. Urolithiasis Research. New York: Plenum Press, 1976: 455-8.

35 Drum D E, Goldman P A, Jankowski C B. Elevation of serum uric acid as a clue to alcohol abuse. Arch Intern Med 1981; 141: 477-9.

36 Delbarre F, Auscher C, Brouilhet H, de Géry A. Action de l.'éthanol dans la goutte et sur le métabolisme de l'acide urique. Sem Hop Paris 1967; 43: 659-64.

37 Yu T S F, Sirota J H, Berger L, et al. Effect of sodium lactate infusion on urate clearance in man. Proc Soc Exp Biol Med 1957; 96: 809-13.

38 Lieber C S, Jones D P, Losowsky M S, Davidson C G. Interrelation of uric acid and ethanol metabolism in man. J Clin Invest 1962; 41: 1863-70.

39 Maclachlan M J, Rodnan G P. Effects of food, fast and alcohol on serum uric acid and acute attacks of gout. Am J Med 1967; 42: 38-57.

40 Spring J A, Buss D H. Three centuries of alcohol in the British diet. Nature 1977; 270: 567-72.

41 Brochner-Mortensen K. Heberden Oration: Gout. Ann Rheum Dis 1958; 17: 1-8.

42 Griebsch A, Zollner N. Effect of ribomononucleotides given orally on uric acid production in man. Adv Exp Med Biol 1974; 41B: $435-42$.

43 Zollner N, Griebsch A. Diet and gout. Adv Exp Med Biol 1974; 41B: $435-42$

44 Clifford A J, Riumallo J A, Young V R, Scrimshaw N S. Effect of oral purines on serum and urinary uric acid of normal, hyperuricaemic and gouty humans. $J$ Nutr 1976; 106: 428-50.

45 Watson A R, Evans D I K, Simmonds H A., et al. Purine nucleoside phosphorylase deficiency: a pharmacological approach to therapy. Submitted for publication.

46 Clifford A J, Story D L. Levels of purines in foods and their metabolic effects in rats. $J$ Nutr 1976; 106: 435-42.

47 Zollner N. Influence of various purines on uric acid metabolism. Nephron 1973; 19: 34-43.

48 Gibson T, Hannon S F, Hatfield P J, et al. The effect of acid loading on renal excretion of uric acid and ammonium in gout. Adv Exp Med Biol 1977; 76B: 46-55.

49 Nugent $C$ A. Renal urate excretion in gout studied by feeding ribonucleic acid Arthritis Rheum 1965; 8: 671-85.

50 Gibson T, Highton J, Potter C, Simmonds H A. Renal impairment and gout. Ann Rheum Dis 1980; 39: 417-23. 